CLINICAL STUDY

\title{
A novel germline mutation in the TSH receptor gene causes non-autoimmune autosomal dominant hyperthyroidism
}

\author{
Luisella Alberti ${ }^{1}$, Maria Carla Proverbio ${ }^{3}$, Sabine Costagliola ${ }^{4}$, Giovanna Weber ${ }^{3}$, Paolo Beck-Peccoz ${ }^{2}$, \\ Giuseppe Chiumello ${ }^{3}$ and Luca Persani ${ }^{1}$ \\ Institute of Endocrine Sciences, University of Milan, ${ }^{1}$ Istituto Auxologico Italiano IRCCS and ${ }^{2}$ Ospedale Maggiore IRCCS, Milan, Italy, ${ }^{3}$ Department of \\ Pediatrics, University of Milan, Scientific Institute H.S. Raffaele, Milan, Italy and ${ }^{4}$ Institut de Recherche Interdisciplinaire, University of Brussels, \\ Belgium
}

(Correspondence should be addressed to Luca Persani, Laboratorio di Ricerche Endocrinologiche, Istituto Auxologico Italiano IRCCS, Via Ariosto 13, 20145 Milano, Italy; Email: persani@auxologico.it)

\begin{abstract}
Objective: Clinical and genetic investigations were undertaken in a case of familial hyperthyroidism, with onset of thyrotoxic symptoms varying between childhood/adolescence.

Methods: Automatic sequence analysis was carried out of the TSH receptor (TSHR) gene. Functional studies were undertaken of mutant TSHR in transient expression experiments in COS-7 cells including the evaluation of cAMP accumulation and of protein expression by flow cytometry, as well as the calculation of specific constitutive activity (SCA).

Results: In four affected cases, the age of onset of thyrotoxic manifestations of non-autoimmune origin varied between 5 and 18 years. The disease transmission was typically autosomal dominant. TSHR gene sequence revealed the presence of a germline heterozygous substitution at codon 597 leading to the novel mutation V597F. This residue is located in the 5th transmembrane domain of the receptor protein in a critical region for membrane targeting and signal transduction. Functional studies of the V597F mutant indicate an 11-fold increase in SCA, associated with a reduction in receptor protein expression on the cytoplasmic membrane.

Conclusions: Description was made of a family with non-autoimmune autosomal dominant hyperthyroidism carrying a novel mutation of TSHR leading to the increment in specific constitutive activity. Factors that may influence the clinical expression of TSHR germline mutations are discussed.
\end{abstract}

European Journal of Endocrinology 145 249-254

\section{Introduction}

Autoimmunity (Graves' disease) is the major cause of thyrotoxicosis in early infancy and childhood (1). Germline gain-of-function mutations of thyrotropin (TSH) receptor (TSHR) have been found to cause nonautoimmune hyperthyroidism with neonatal to juvenile onset (2). The sporadic cases so far reported presented already at birth or in infancy with severe thyrotoxic manifestations and goiter (3-9), whereas a delayed and progressive onset of hyperthyroidism with milder clinical manifestations was generally observed in the cases with inherited mutation of the TSHR gene (10-13). The reasons for such a variable age of onset and degree of disease manifestation may be attributed either to the type of the mutation or to other endogenous or exogenous factors. Typically, the disease is persistent with immediate relapses after withdrawal of anti-thyroid drugs, and sporadic cases are frequently resistant to medical treatment. Therefore, total thyroidectomy is the treatment of choice in these situations.
We report a new family with non-autoimmune autosomal dominant hyperthyroidism due to a novel germline mutation of the thyrotropin receptor gene.

\section{Materials and methods}

\section{Case report}

The propositus is a female born after normal gestation. Her family originates from the Romagna region in Italy. She was seen at 5 years of age for high stature accompanied in the last months by progressive worsening of symptoms such as hyperactivity, irritability, and palpitations. Physical examination showed mild signs of thyrotoxicosis with a small goiter: her heart rate was 120 beats/min, blood pressure was 130/70 mmHg. Her body weight was $34 \mathrm{~kg}$, and her height was above the 97 th centile: $129 \mathrm{~cm}$. She had no sign of sexual maturation and no skin lesions. The biochemical investigations showed TSH: <0.01 mU/l (normal value (n.v.) $0.24-4.0$ ); free thyroxine $\left(\mathrm{FT}_{4}\right)$ : 


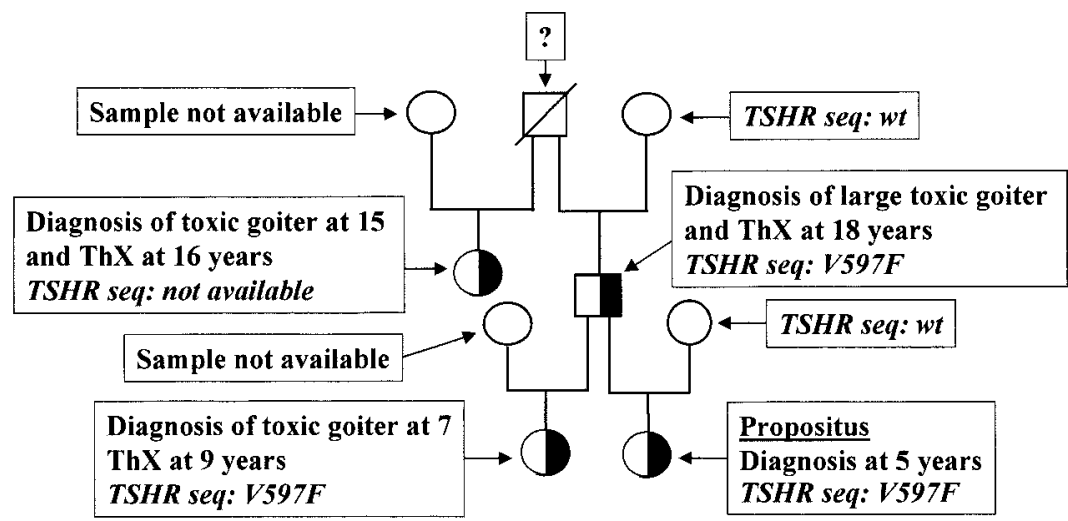

Figure 1 The pedigree of the family with an indication of the members affected with nonautoimmune toxic goiter. Whole blood DNA could not be obtained in the case of the grandfather and the aunt of the proband, who were likely carriers of the mutation. seq., sequence; wt, wild-type; ThX, thyroidectomy.
$45.6 \mathrm{pmol} / \mathrm{l}$ (n.v. 9-18); free tri-iodothyronine $\left(\mathrm{FT}_{3}\right)$ : $15.6 \mathrm{pmol} / \mathrm{l}$ (n.v. 4-8) in the absence of anti-thyroid auto-antibodies, including anti-thyroperoxidase, antithyroglobulin, as well as anti-TSH receptor (TRAb). Serum levels of $\beta$-chorionic gonadotropin and $17 \beta$ estradiol were below the detection limits. Ultrasound showed a moderate and diffuse thyroid enlargement $(5.8 \mathrm{ml})$ with normal ecogenicity. Thyroid scintiscan showed a diffuse ${ }^{99} \mathrm{Tc}$ uptake. Ovary ultrasound was normal, as was skull magnetic resonance imaging. Orbital ultrasound did not show any sign of associated ophthalmopathy. Her bone age was 7 years (2 years in advance of chronological age, but 1.5 years retarded for statural age). Dual-energy X-ray absorptiometry (DXA) showed reduced bone density for age. Serum growth hormone $(\mathrm{GH})$ levels were $0.1 \mathrm{ng} / \mathrm{ml}$ in 3 different determinations, but insulin-like growth factor-I (IGF-I) was high $(325 \mathrm{ng} / \mathrm{ml}$; n.v. for age: 14-194; n.v. for bone age: $24-220$ ). The family history revealed that her father, her paternal aunt and elder half-sister (the child of her father's first marriage) underwent total thyroidectomy for non-autoimmune hyperthyroidism and large goiter at 18, 16 and 9 years respectively (Fig. 1).

After informed consent, blood was obtained from the propositus and all the available family members for genetic analyses.

The patient was initially treated with methimazole (MMI) $0.3 \mathrm{mg} / \mathrm{kg}$ body weight (bw)/day, but no clinical nor biochemical response was seen after 40 days (TSH $\left.<0.01 \mathrm{mU} / \mathrm{l} ; \mathrm{FT}_{4}: 41.4 \mathrm{pmol} / \mathrm{l} ; \mathrm{FT}_{3}: 17.1 \mathrm{pmol} / \mathrm{l}\right)$. The dose of MMI was then augmented to $0.6 \mathrm{mg} / \mathrm{kg}$ bw/day. After 75 days, a clinical improvement with normalization of the heart rate ( 80 beats $/ \mathrm{min}$ ) and circulating free thyroid hormones was seen $(\mathrm{TSH}<0.01 \mathrm{mU} / \mathrm{l}$; $\mathrm{FT}_{4}$ : $\left.15.8 \mathrm{pmol} / \mathrm{l} ; \mathrm{FT}_{3}: 7.3 \mathrm{pmol} / \mathrm{l}\right)$. This was accompanied by the normalization of circulating IGF-I (157 ng/ml) after 3 months.

\section{DNA analyses}

Genomic DNA was extracted from peripheral whole blood of the proband and of her father, mother, grandmother, and elder half-sister (see Fig. 1), using a commercial kit (Nucleon BACC2, Amersham Pharmacia Biotech Italia, Cologno Monzese, Italy) according to the manufacturer's instructions. The fragments containing the whole length of exon 10 of the TSHR gene were amplified by PCR as previously described (14). The purified PCR products were directly sequenced in both forward and reverse directions using the Big Dye Terminator kit and resolved by capillary electrophoresis on an ABI 310 Automated Sequencer (PE Biosystems, Foster City, CA, USA). The sequence was confirmed using two different PCR products.

\section{Cloning and mutagenesis of TSHR}

cDNA encoding the human TSHR was obtained by RTPCR from normal thyroid tissue using the following primers, 1 forward: 5'-GAGGATGGAGAAATAGCCCCGAG-3' and 10 reverse: 5'-GTGTCATGGGATTGGAAT$3^{\prime}$ (15), and was cloned into the polylinker of the eukaryotic expression vector pTarget (Promega, Madison, WI, USA). The insert was entirely sequenced.

The substitution observed in this study was introduced by site-directed mutagenesis using the GeneEditor in vitro site-directed mutagenesis system (Promega) and the following primer 5'-GCCTTCGTCATCTTCTGCTGCTGTT-3' (the substituted base is in bold and italic). Two full-length TSHR clones carrying the mutations were entirely sequenced to verify possible differences other than the missense mutation itself.

\section{Cell culture and transient transfection}

COS-7 cells were grown in Dulbecco's modified Eagle's medium (DMEM, Gibco BRL, Life Technologies Italia, San Giuliano Milanese, Italy) containing 10\% fetal calf serum (FCS) and antibiotics. For transient transfection, cells were seeded at a density of 300000 cells $/ 3 \mathrm{~cm}$ dish and transfected with $0.5 \mu \mathrm{g}$ of specific DNA by the DEAE-Dextran method, followed by a DMSO shock 
(16). Cells were then grown in DMEM/10\% FCS for $48 \mathrm{~h}$ before cAMP determination and flow cytometry experiment.

\section{cAMP determination}

The culture medium was removed and replaced with Krebs-Ringer-HEPES (KRH) buffer, 0.5\% BSA, for $30 \mathrm{~min}$ at $37{ }^{\circ} \mathrm{C}$. Then cells were incubated at $37{ }^{\circ} \mathrm{C}$ for $60 \mathrm{~min}$ in fresh $\mathrm{KRH}$ buffer, $0.5 \% \mathrm{BSA}$, supplemented with $0.5 \mathrm{mmol} / \mathrm{l}$ isobutylmethylxanthine (IBMX) and the indicated concentrations of bovine (b) TSH (Sigma-Aldrich srl, Milan, Italy). The medium was removed and the reaction stopped by adding $0.1 \mathrm{~mol} / \mathrm{l}$ $\mathrm{HCl}$. Samples were dried and cAMP was measured using a commercial assay kit (RIANEN, NEN Life Science Products Inc., Boston, MA, USA). The results were expressed in pmoles/dish.

\section{Flow cytometry}

Flow cytometry experiments were performed as previously described (17). For permeabilization, cells were incubated with PBS-paraformaldehyde $2 \%$ in ice for 10 min, washed once with PBS-BSA $0.1 \%$ and treated with $2 \%$ saponine at room temperature for $30 \mathrm{~min}$. Permeabilized and non-permeabilized cells were labeled with 3G4 monoclonal antibody recognizing a linear epitope, and with BA8 antibody recognizing a conformational epitope, both within the ligand-binding domain of TSHR (18).

\section{Computation of specific constitutive activity}

The fold cAMP constitutive activity above mocktransfected COS-7 cells was calculated for each receptor construct, and then normalized for their own level of expression, as previously described (19). Specific constitutive activity (SCA) of the mutant was then expressed as fold-increase over the wild-type (19).

\section{Statistical analysis}

Data were analyzed by Student's $t$-test and analysis of variance (ANOVA), as appropriate. $P$ values $<0.05$ were considered statistically significant. Results are expressed as means \pm standard deviation (s.D.).

\section{Results}

\section{DNA analysis}

Automatic sequencing of DNA obtained from peripheral whole blood of the propositus revealed a heterozygous $\mathrm{G}$ to $\mathrm{T}$ transversion at codon 597 in the TSHR gene leading to the missense substitution V597F (Fig. 2). This codon is located in the fifth transmembrane domain of the receptor. Both the father and the half-

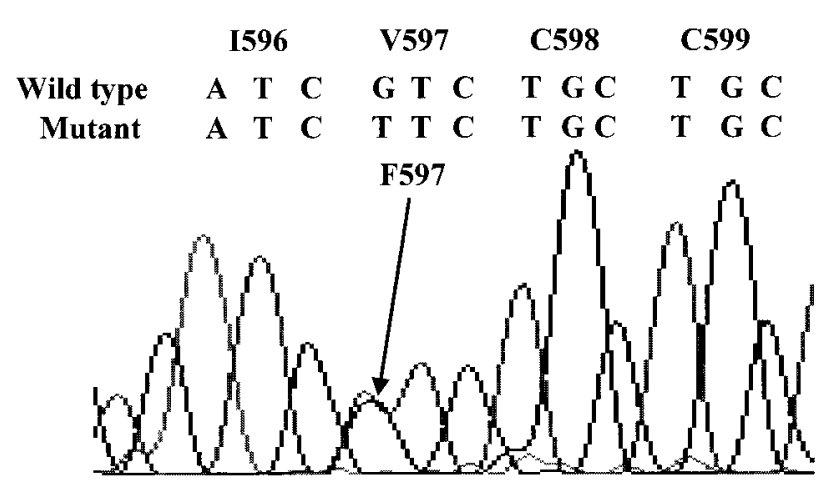

Figure 2 Electropherogram of dye terminator sequencing around codon 597 (arrow) of the TSHR gene in the proband and in the other affected members of the family. The double peak indicates the presence of two bases ( $\mathrm{G}$ or $\mathrm{T})$ at that position.

sister of the propositus were heterozygote for the same substitution, whereas the TSHR sequence was of the wild-type (WT) in the mother and the paternal grandmother (Fig. 1).

\section{Functional studies of mutant receptor}

Flow cytometry experiments, one of which is shown in Fig. 3, indicate that the synthesis of TSHR-WT and TSHR-V597F constructs are not significantly different as demonstrated in permeabilized cells, but the receptor carrying the activating mutation displays a reduced expression level on the cell surface. The entity of this reduction is $60 \%$ of that observed with normal receptor using the $3 \mathrm{G} 4$ antibody (Fig. 3A). Expression of the V597F mutant was even lower (25\% vs wild-type) when the BA8 monoclonal antibody directed against a conformational epitope was used (Fig. 3B).

In order to evaluate the activity of the V597F mutant receptor, we measured basal and TSH-stimulated cAMP accumulation in transiently transfected COS-7 cells in several experiments $(n=7)$. As shown in Fig. 4, expression of the V597F mutant receptor always resulted in a marked increase in basal cAMP production when compared with the wild-type receptor or mock-transfected cells. The V597F mutant maintained the ability to respond to TSH stimulation, although the increment in cAMP production at $10 \mathrm{U} / \mathrm{l}$ bTSH is 2.4 -fold lower than that of wild-type (Fig. 4). Maximal cAMP stimulation was reached at $10 \mathrm{U} / \mathrm{l}$ bTSH in both cases. On this basis,

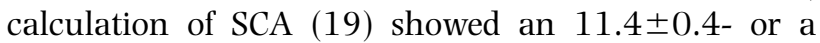
$4.6 \pm 0.2$-fold increase over the wild-type receptor in intact and permeabilized cells respectively.

\section{Discussion}

We report a new case of non-autoimmune autosomal dominant hyperthyroidism. In this family, thyrotoxic manifestations and goiter had a childhood to juvenile onset, ranging from 5-18 years of age in the four 
(A) $3 \mathrm{G} 4 \mathrm{Ab}$

\section{Intact cells}
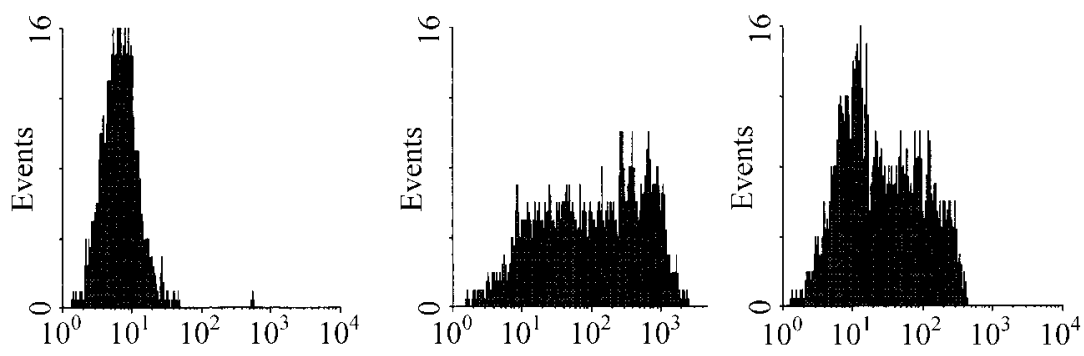

\section{Permeabilized}

\section{cells}
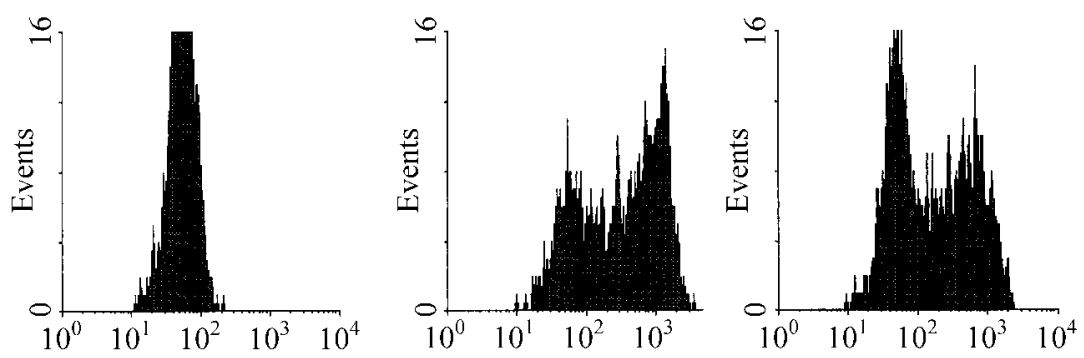

(B) BA8 Ab

\section{Intact cells}
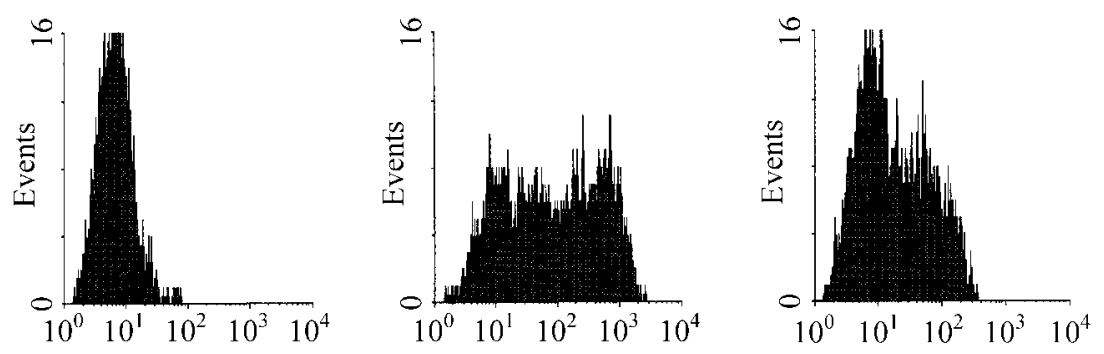

\section{Permeabilized cells}
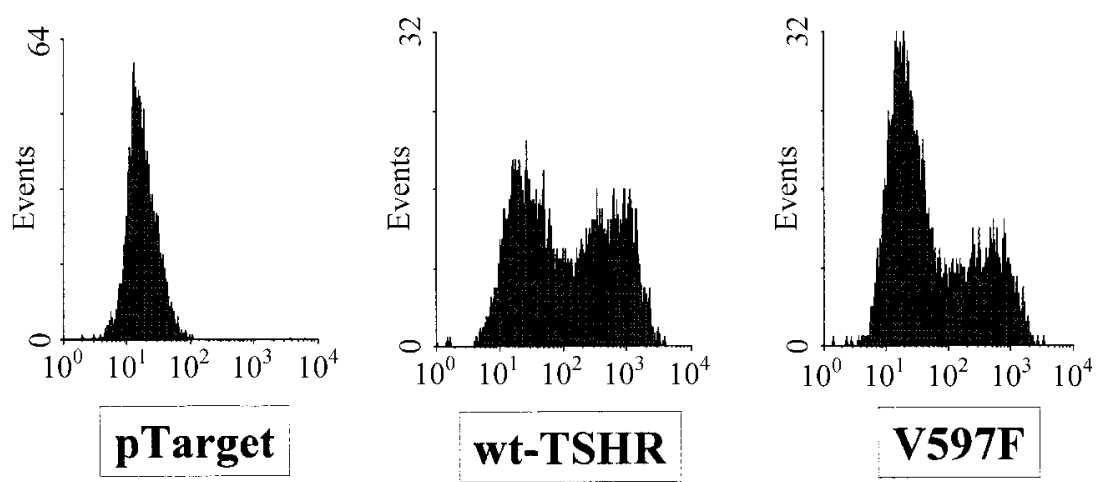

Figure 3 Representative flow cytometry experiment, using $3 G 4$ (A) and BA8 (B) monoclonal antibodies (Ab), for the analysis of wild-type (wt) and V597F TSHR protein expression in intact and permeabilized cells. Results with mock transfected cells (pTarget) are also shown. These data demonstrate a reduced expression of V597F mutant TSHR protein on the membrane of intact COS-7 cells. 


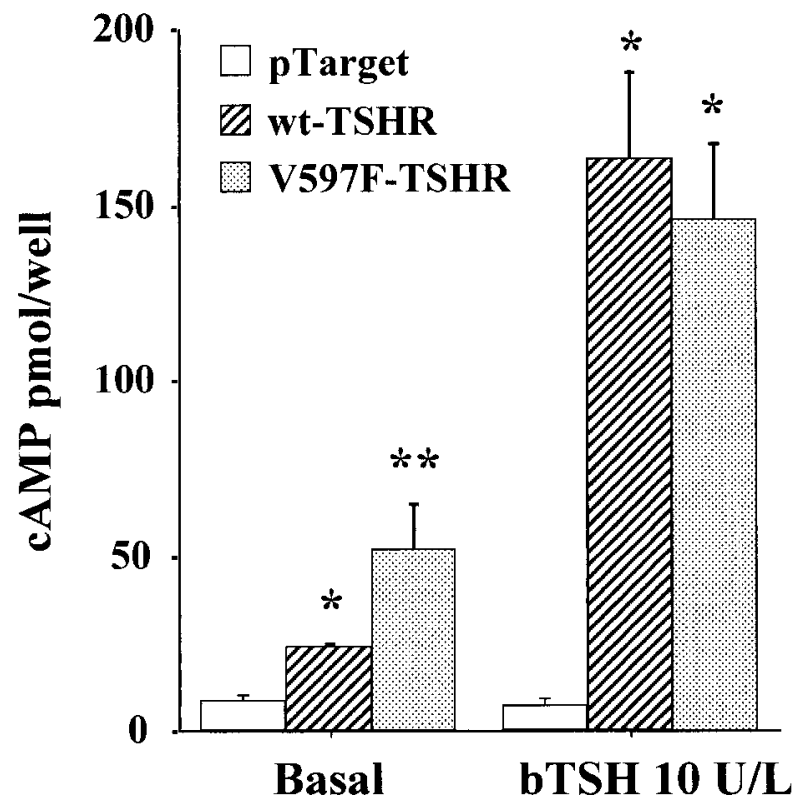

Figure 4 Functional studies of wild-type (wt) TSHR and V597F mutant in transient transfection in COS-7 cells. The results of basal and TSH-stimulated cAMP accumulation in one representative experiment are shown (means \pm S.D. of three different determinations). pTarget, mock transfected cells. ${ }^{*} P<0.05$ vs pTarget; ${ }^{* \star} P<0.05$ vs wild-type TSHR.

affected members. Automatic sequencing of the TSHR gene using genomic DNA from the propositus and the other affected relatives revealed the presence of a novel heterozygous germline transversion at codon 597 (GTC to TTC). This mutation leads to the amino acid substitution V597F in the fifth transmembrane domain of the receptor. Molecular and functional studies allowed us to reach the correct diagnosis of nonautoimmune autosomal dominant hyperthyroidism.

The biological function of this mutant receptor was evaluated by transient transfection in COS-7 cells, in comparison with normal receptor. The V597F substitution causes a marked increase in ligand-independent receptor activity, despite the fact that flow cytometry experiments showed a marked reduction in cell surface expression of this mutant in COS-7 cells compared with the wild-type receptor. The reduction in cell surface expression could be due to an abnormal folding of the mutant receptors preventing the correct membrane targeting. The lower expression levels given at the analysis with the monoclonal antibody against a conformational epitope, such as BA8 (18), may also be due to the altered immunoreactivity of the mutant receptor. The presence of the $\mathrm{V} 597 \mathrm{~F}$ mutant on the plasmatic membrane is confirmed by the conserved response to TSH stimulation. The same codon was recently found mutated with a different substitution (V597L) in one infant with severe thyrotoxicosis (8). Functional experiments of the V597L TSHR mutant showed a dramatic increase in ligand-independent receptor activity associated with the severe impairment of membrane targeting, leading to a diminished response to TSH stimulation. The increase in specific constitutive activity of the V597L mutant was markedly higher than that observed in the case of V597F (28.9- vs 11.4-fold over wild-type in intact cells). As in other G proteincoupled receptors (20), the intramolecular interactions between hydrophobic residues in the fifth and sixth transmembrane domains would contribute to the structural inhibitory constraint keeping the TSHR in its basal state (21). V597 residue is one of the hydrophobic residues involved in this structural inhibitory constraint and mutations at this residue are expected to alter constitutive receptor activity. However, the differences in specific constitutive activity between V597L and V597F are difficult to explain. In fact, both leucine and phenylalanine have non-polar side chains like valine, and the bulkier side chain of phenylalanine would be expected to produce a more profound disruption of the structural inhibitory constraint.

Although caution is advised in interpreting data obtained in a heterologous system, the reported differences in the in vitro functional characteristics of the two mutants affecting the same V597 residue are mirrored by the clinical phenotype recorded in the affected patients. In fact, the V597L mutation was found in one sporadic case with infantile onset (at 9 months of age) of severe thyrotoxic features (8), whereas V597F is associated with a childhood to juvenile onset of thyrotoxic features. Germline mutations causing dramatic increases in TSHR constitutive activity causing severe thyrotoxicosis since early infancy (or even congenital) (3-9) may be associated with intellectual impairment and craniosynostosis in later years (22), and familial vertical transmission may become unlikely. Alternatively, this would not be prevented in the case of germline mutations with less dramatic effects on TSHR function (10-13). Consistently, the inherited TSHR mutations generally present later in life (typical childhood or juvenile onset) with mild to moderate thyrotoxic manifestations. Hyperstaturism was described in our proband and bone was severely affected, indicating that, despite mild and unrecognized clinical symptoms, tissue thyrotoxicosis had been long-standing. Increased growth velocity was, at least in part, mediated by the thyroid hormonedependent induction of IGF-I secretion from the liver, perhaps through the stimulation of hepatic growth hormone receptor gene expression, as already seen in the chicken (23). Consistently, increased IGF-I secretion reverted to normal during MMI treatment.

Increased medical awareness and improvement in diagnostic testing (such as availability of ultrasensitive TSH assay) (24) throughout the last decades could have allowed the earlier diagnosis in the proband. Nevertheless, the clinical expression of the same alteration of the TSHR gene in the different members of one family may also be influenced by several 
environmental (such as modifications in iodine intake) and/or endogenous (such as sex) factors. During the 1980 s, when the father and aunt of our proband both underwent thyroidectomy and before the prophylaxis with iodized salt was well-established, the mean urinary excretion of iodine was as low as $58.1 \mu \mathrm{g} / \mathrm{l}$ in the Romagna region (25). Accordingly, the diagnosis of thyrotoxicosis was reached at 15 and 18 years in the older members of the family and at 5 years in the proband. Differently from what is usually seen in sporadic cases, hyperthyroidism could be controlled by high doses of methimazole. However, progressive thyroid growth is expected through the years and strict ultrasound monitoring is advocated during treatment in order to program thyroid surgery before the formation of a large goiter, as already seen in her affected relatives.

\section{Acknowledgements}

This work was partially supported by Funds of the Ricerca Corrente of Istituto Auxologico Italiano IRCCS (to $\mathrm{L} \mathrm{A}$ and $\mathrm{L} \mathrm{P}$ ).

\section{References}

1 Lafranchi S \& Hanna CE. Graves' disease in the neonatal period and childhood. In Werner and Ingbar's The Thyroid: A Fundamental and Clinical Text. 8th edition, pp 989-997. Eds LE Braverman \& RD Utiger. Philadelphia: Lippincott Williams \& Wilkins, 2000.

2 Duprez L, Parma J, Van Sande J, Rodien P, Dumont JE, Vassart G et al. TSH receptor mutations and thyroid disease. Trends in Endocrinology and Metabolism 19989 133-140.

3 Kopp P, Van Sande J, Parma J, Duprez L, Gerber H, Joss E et al. Congenital hyperthyroidism caused by a mutation in the thyrotropin receptor gene. New England Journal of Medicine 1995332 150-154.

4 De Roux N, Polak M, Couet J, Leger J, Czernichow P, Milgrom E et al. A neomutation of the thyroid-stimulating hormone receptor in a severe neonatal hyperthyroidism. Journal of Clinical Endocrinology and Metabolism 199681 2023-2026.

5 Holzapfel HP, Wonerow P, von Petrykowski W, Henschen M, Scherbaum WA \& Paschke R. Sporadic congenital hyperthyroidism due to a spontaneous germline mutation in the thyrotropin receptor gene. Journal of Clinical Endocrinology and Metabolism 199782 3879-3884.

6 Kopp P, Jameson JL \& Roe TF. Congenital nonautoimmune hyperthyroidism in a non identical twin caused by a spontaneous germline mutation in the thyrotropin receptor gene. Thyroid $19977765-770$.

7 Gruters A, Schoneberg T, Biebermann H, Krude H, Krohn HP, Dralle $\mathrm{H}$ et al. Severe congenital hyperthyroidism caused by a germline neo mutation in the extracellular portion of the thyrotropin receptor. Journal of Clinical Endocrinology and Metabolism 199883 1341-1346.

8 Esapa CT, Duprez L, Ludgate M, Mustafa MS, Kendall-Taylor P, Vassart $\mathrm{G}$ et al. A novel thyrotropin receptor mutation in an infant with severe thyrotoxicosis. Thyroid $199991005-1010$.

9 Tonacchera M, Agretti P, Rosellini D, Ceccarini G, Perri A, Zampolli $\mathrm{N}$ et al. Sporadic nonautoimmune congenital hyperthyroidism due to a strong activating mutation of the thyrotropin receptor gene. Thyroid $200010859-863$.

10 Duprez L, Parma J, Van Sande J, Allgeier A, Leclerc J, Schvartz C et al. Germline mutations in the thyrotropin receptor gene cause non-autoimmune autosomal dominant hyperthyroidism. Nature Genetics $19947396-401$.
11 Tonacchera M, Van Sande J, Cetani F, Swillens S, Schvartz C, Winiszewski $\mathrm{P}$ et al. Functional characteristics of three new germline mutations of the thyrotropin receptor gene causing autosomal dominant toxic thyroid hyperplasia. Journal of Clinical Endocrinology and Metabolism $1996 \mathbf{8 1} 547-554$.

12 Fuhrer D, Wonerow P, Willgerodt H \& Paschke R. Identification of new thyrotropin receptor germline mutation (Leu629Phe) in a family with nonautoimmune hyperthyroidism. Journal of Clinical Endocrinology and Metabolism 199782 4234-4238.

13 Schwab KO, Gerlich M, Broecker M, Sohlemann P, Derwahl M \& Lohse MJ. Constitutively active germline mutation of the thyrotropin receptor gene as a cause of congenital hyperthyroidism. Journal of Pediatrics 1997131 899-904.

14 Persani L, Lania A, Alberti L, Romoli R, Mantovani G, Filetti S et al. Induction of specific phosphodiesterase isoforms by constitutive activation of the cAMP pathway in autonomous thyroid adenomas. Journal of Clinical Endocrinology and Metabolism 2000 $852872-2878$.

15 de Roux N, Misrahi M, Chatelain M, Gross B \& Milgrom E. Microsatellites and PCR primers for genetic studies and sequencing of the human TSH receptor. Molecular and Cellular Endocrinology $1996117253-256$.

16 Parma J, Van Sande J, Swillens S, Tonacchera M, Dumont J \& Vassart G. Somatic mutations causing constitutive activity of the thyrotropin receptor are the major cause of hyperfunctioning thyroid adenomas: identification of additional mutations activating both the cyclic adenosine $3^{\prime}, 5^{\prime}$-monophosphate and inositol phosphate-Ca ${ }^{2+}$ cascades. Molecular Endocrinology 19959 725733.

17 Parma J, Duprez L, Van Sande J, Hermans J, Rocmans P, Van Vliet $\mathrm{G}$ et al. Diversity and prevalence of somatic mutations in the thyrotropin receptor and Gs $\alpha$ genes as a cause of toxic thyroid adenomas. Journal of Clinical Endocrinology and Metabolism 1997 82 2695-2701.

18 Costagliola S, Khoo D \& Vassart G. Production of bioactive amino-terminal domain of the thyrotropin receptor via insertion in the plasma membrane by a glycosylphosphatidylinositol anchor. FEBS Letter $1998 \mathbf{4 3 6} 427-433$.

19 Duprez L, Parma J, Costagliola S, Hermans J, Van Sande J, Dumont JE et al. Constitutive activation of the TSH receptor by spontaneous mutations affecting the N-terminal extracellular domain. FEBS Letter $1997 \mathbf{4 0 9} 469-474$.

20 Lefkowitz RJ, Cotecchia S, Samana P \& Costa T. Constitutive activity of receptors coupled to guanine nucleotide regulatory protein. Trends in Pharmacological Sciences 199314 303-307.

21 Biebermann H, Schonberg T, Schulz A, Krause G, Gruters A, Schultz $G$ et al. A conserved tyrosine residue (Y601) in transmembrane domain 5 of the human thyrotropin receptor serves as a molecular switch to determine G-protein coupling. FASEB Journal $1998121461-1471$.

22 Daneman D \& Howard NJ. Neonatal thyrotoxicosis: intellectual impairment and craniosynostosis in later years. Journal of Pediatrics $198097257-259$.

23 Tsukada A, Ohkubo T, Sakaguchi K, Tanaka M, Nakashima K, Hayashida Y et al. Thyroid hormones are involved in insulin-like growth factor-I (IGF-I) production by stimulating hepatic growth hormone receptor (GHR) gene expression in the chicken. Growth Hormone and IGF Research 19988 235-242.

24 Caldwell G, Kellet HA, Gow SM, Beckett JG, Sweeting VM, Seth J et al. A new strategy for thyroid function testing. Lancet $1985 \mathbf{1}$ 1117-1119.

25 Antonangeli L \& Aghini-Lombardi F. Schede regionali di rilevamento. In Carenza Iodica e Gozzo Endemico in Italia. Guida Pratica alla Epidemiologia e Prevenzione. Rapporto 1994 a cura del Comitato Nazionale per la Prevenzione del Gozzo, pp 61-85. Eds A Pinchera, G Salvatore, G Faglia \& R Vigneri. Milano: Mediserve, 1995.

Received 23 January 2001

Accepted 30 May 2001 